\title{
L. A sketch of the topography and geology of Lake Ontario
}

\section{J.J. Bigsby M.D. F.L. G.S.}

To cite this article: J.J. Bigsby M.D. F.L. G.S. (1829) L. A sketch of the topography and geology of Lake Ontario, Philosophical Magazine Series 2, 5:29, 339-347, DOI: 10.1080/14786442908675014

To link to this article: http://dx.doi.org/10.1080/14786442908675014

里 Published online: 10 Jul 2009.

Submit your article to this journal $₫$

Џ Article views: 2

Q View related articles $๘$ 
parts of the cerebral portion of the nervous system, and as this system requires to be studied as a whole, in order to confirm the particulars which may have been discovered, we shall confine ourselves to the recommendation, that the Academy strongly encourage Dr. Foville to pursue his researches with caution, and to avail himself of the light of comparative anatomy; and that he be advised not to hasten the publication of any observations, until they appear to himself to be placed completely beyond doubt, and to be susceptible of the most rigorous demonstration. They serve science poorly who encumber her with ill-prepared materials, however copious and specious they may be.-These considerations alone have diverted us from a conclusion in favour of publishing Dr. Foville's Researches on the Brain, so far as they have been communicated to us, amongst the collections of the Academy, of which they appear to us perfectly worthy, on the double ground of their own interest, and of the good faith with which they have been brought forward.
(Signed) Dumeril, and
D. De Blainville (the Reporter).
Certified as a true copy, G. Cuvien, Perpetual Secretary, Counsellor of State, \&cc.

L. A Sketch of the Topography and Geology of Lake Ontario. By J. J. Bigsby, M.D. F.L. and G.S., For. Mem. Amer. Phil. Soc. \&c.

[Continued from page 274.]

THERE now succeeds the stratum, which by way of eminence, Mr. Eaton denominates the Saliferous Rock. It is itself very much the same as the English stratum; but the sandstones directly above it differ in containing a large amount of iron. I am inclined to consider this rock, the ferriferous slate and sandstone of Mr. E., his calciferous slate and the geodiferous rock, to belong to the same formation,- that producing the salt. They are all conformable to each other. I know that many, and I believe that all of them, run into each other. The ferriferous slate and sandstone sometimes alternate. The geodiferous rock abounds in gypsum; but not by any means so extensively as the calciferous slate. In the saliferous group which I have instituted, the gypsum occupies here the upper beds as in Europe. Their whole thickness is by no means equal to that of the red marl of England, its supposed representative*.

* At p. 138 of our present volume will be found a different arrangement, by Mr. Featherstonehaugh, of the formations which appear to be the equivalents of Mr. Eaton's series,-Eidit. 
Saliferous Rock of Mr. Eaton is an aggregate of minute rounded grains of quartzose sand, simply, or mingled with argillaceous, so forming red or greenish sandstone, or soft red or greenish brittle clayslate. The sandstone kind is distinguished from the old red sandstone by its rounded grains, as they appear under the magnifier, and by its not containing glimmering scales, except in rare cases.-(G. S. p. 35.)

"From near Little Falls to the west end of Lake Ontario, this rock may be traced in the most satisfactory manner. It is about 250 miles in length*, and something more than twenty miles in breadth on an average (on the south shore of Lake Ontario exclusively). Its thickness, where it crops out in Steel's Creek, and some other places,' will average about eighty feet. But a Mr. Bennett bored into it 140 feet, from the bottom of Oak Orchard Creek, seven miles south of Lake Ontario, and did not reach its lower surface. At and below the Genesee Falls, and at the mouth of the Niagara River, a thickness about equal to Mr. Bennett's boring may be seen, without any evidence of a near approach to its next underlaying stratum.

"This rock is manifestly the floor of all the salt springs of the canal district. It descends like an inclined plane to the Genesee River, where it is about 250 feet lower than at the ridge between Little Falls and Utica, where it crops out and terminates. From Genesee River westerly it is an ascending plane. It rises up to the canal level eight miles west of that river; though where it crosses the river on the same level, the upper surface of the rock is considerably more than one hundred feet below it. This difference, however, does not depend wholly on' the general western ascent of the rock; for it also ascends as it recedes from the lake. To have a correct conception of the form of this rock, we must view it as the southern side or brim of the great elliptical basin which holds the waters of Lake Ontario."-(G. S. p. 103, 104.)

“ Beginning at its eastern limit, where it crops out, near Little Falls on the Mohawk, we find no salt springs within about twenty miles.

" Throughout this twenty miles, the rock is mostly of the red sandstone kind, and more coarse and harsh than it is further west. But near Vernon Centre, seven miles south of the canal, where the first salt spring occurs, the red slate appears with the red sandstone in considerable proportion.

" This spring issues from the upper surface of the rock on the west side of Skanando Creek ; whose banks consist of the soft red saliferous slate, beautifully spotted with nodnles of green slate, resembling the ferriferous slate.

* Meaning, as visible here; for it extends throughout the Basins of Lake Erie ànd Mississippi. 
"The next spring which $I$ saw is about nine or ten miles west, on the lands of Sidney Breese, Esq. There is another in the same direction in Lennox, and about the same distance from the last. The descent of the rock is very uniform along the line of these springs, and also all the way to Salina or the Onondaga spring. The springs further west, as Montezuma, Clyde, \&c. are still deeper; probably in the same ratio. Beyond the Genesee River they are more elevated, according to the ascending course of the rock. The descent of this rock in a north direction towards Lake Ontario is not uniform. It falls away by offsets, like the grauwacke of Cattskill Mountains; differing greatly, however, in degree. The edge of the principal offset forms a kind of ridge whereon a road is constructed, called ' Ridge Road."'-(G. S. p. 104.)

"We have a most excellent view of this saliferous rock, with the five next strata above it, in Genesee River near Rochester ; in Irondiquet Creek, four miles east; throughout the whole extent of the south shore of Lake Ontario, at short intervals, and in the chasm of Niagara River. It is also brought into sight by the disintegration of the overlying ferriferous rocks at intervals from Little Falls to Oneida Creek, within a breadth of ten miles south of the canal."-(G. S. p. 108.)

$\mathrm{Mr}$. Eaton states that with ample opportunities of discovering any rock salt by borings, ravines, \&c., none has been found; and he thinks that the brine is produced from elementary materials contained in this and the higher rocks (p. 109).* He believes that the salt is diffused through the whole of the strata; but that the strongest waters are at the bottom, as has been verified at Salina and Oak Orchard Creek. At the latter place the rock was bored to the extent of 140 feet, when the conglomerate was found below it.

A specimen of the dry salt of Salina, analysed by Dr. $M^{\circ}$ Neven of New York, furnished, 93.194 parts of muriate of soda, 2.525 sulphate of potash, 2.269 of muriate of lime, and $2 \cdot 412$ of muriate of magnesia.

No rock salt is found in any of the muriatiferous formations of North America, excepting those of California.

Grayband:-A single stratum of trifling thickness, which rests upon the saliferous slate, has received a separate name (as above) from Mr. Eaton. Its only title to such distinction is its extent. It evidently belongs to the salt formation, like a similar layer at Runcorn and Manley in Cheshire. (Geological Survey of England, Conybeare and Phillips, p. 280).Mr. Eaton describes it as a hard-grained gray. homogeneous

* See also Silliman's Amer. Journ. of Science, vol. vi. p. 242.-Eort.

rock. 
rock. It is a thin stratum, but continuous for 200 to 300 miles. It is four feet thick at Genesee Falls, eight feet at Niagara River, twelve feet on the creek east of Lockport, and fifteen feet at most places; where it crops out with the saliferous rock, near the Mohawk. It varies considerably, however, in its texture and its constituents. In some places it seems to be considerably argillaceous; in others, quartzy; and in others again, it contains considerable carbonate of lime.-(G.S. p.115, 116.)

Above this grayband are placed conformably two sets of strata abounding in iron ore. The lowest of these Mr. Eaton names

Ferriferous Slate, describing it as soft, almost homogeneous, argillaceous, greenish-blue and bluish-green; a brittle, generally a shaly slate.-(P. 36.)

This rock is seen frequently in connection with those above and below it: its thickness is variable. At the Genesee Falls it is twenty-three feet thick, perhaps the average. It is but ten feet thick at the Verona Iron Mines. It runs about two miles and a half south of Lake Ontario, from Irondiquet's Bay to Sodus Bay. The iron ore is mostly the argillaceous oxide, sometimes passing into the jaspery variety. The best kind is the lenticular. It being the peroxide of iron combined with alumine, the colour is bright red, and it is of a soft texture. Some specimens may be rubbed into a fine powder between the fingers. It has an unctuous feel, and stains the hands deeply and permanently. Though it will generally give but 30 per cent of iron, it is so easily reduced that it is a very profitable ore. "The jaspery variety is hard, and difficult to reduce. It is not at present used at the furnaces. Sometimes the ore is in a distinct bed or layer between the two ferriferous strata. It is more commonly attached to the upper surface of the slate, and intermixed with the layers of sandstone. Sometimes it is embraced between layers in both rocks. In the banks of Genesee River, at the Falls, it appears like a distinct stratum between the two rocks. It has the same appearance in some cther places. It is so remarkably continuous, that there would perhaps be no impropriety in calling it a stratum of argillaceous iron ore. I have seen it between, and in the, adjoining parts of, these rocks, at frequent intervals from near Little Falls to Queenston in Canada, a distance considerably exceeding two hundred miles. It is never wanting in the canal district, where the ferriferous rocks are present.

"The whole thickness of the iron formation at Genesee Falls is thirty-eight feet. Here the iron ore is but one foot in thickness. In most of the ore beds which are wrought, the ore is twelve to twenty inches in thickness. In several loca- 
lities $I$ have seen two or three beds in succession alternating with layers of the sand rock; rarely with those of the slate rock. The best ore beds (or perhaps, more properly, the best parts of the great stratum of argillaceous iron ore) which are at present wrought are between Little Falls and Oneida Creek on the south side of the canal, and between Lyons and the Genesee River on the north side." West of Genesee River, the iron formation is chiefly on the south side of the canal as far as Lockport*.

Ferriferous Sand-rock is the other stratum, so characterized by $\mathrm{Mr}$. E., from its abounding in iron. He defines it to be " $a$ gray or yellowish gray massive aggregate of quartzose grains, often hyaline, and without cement.

This stratum is fourteen feet thick at the rivers Genesee and Niagara; but at the out-croppings of these two rocks near the Mohawk, and wherever their full thickness is in view, almost to Vernon, the sand-rock is five to ten times the thickness of the slate. This rock is hard, breaking into thick shapeless or square-faced blocks. In some places the two rocks alternate with each other, but generally they are separated by a continuous layer, or extensive bed of argillaceous iron ore."(P. 120.)

"The ore embraced in this rock is more granulated, and has less the appearance of the lenticular form than that which is between it and the slate, or embraced in the slate. More of the jaspery variety is found in it; and sometimes the oxide of iron is in larger proportion, compared with the alumine, than is found in connection with the ferriferous slate-rock."

Calciferous Slate of Eaton next follows. It is " an aggregate of quartzose sand and clay-slate, or other aluminous compounds. Sometimes it is a soft thin slate; but it is often hard, siliceous, and rings more or less on being struck. It is of a gray colour, and can scarcely be distinguished from grauwacke slate in hand specimens with the naked eye. But under the magnifier the constituent particles appear somewhat rounded; and it is nearly or quite destitute of the shining scales."(G. S. p. 37).

This position of this rock is seen very clearly in numberless places, and throughout the whole district now under discus-

* " In the bottom of a well in Salina, at the upper part of the village, fortythree feet deep, this rock presents a very singular structure. The surfaces of the layers, which are about half an inch thick, are marked with angular grooves, so arranged as to resemble the mid-ribs of leaves, with lateral secondary ribs and veins. These appearances are undoubtedly the effect of a crystalline tendency. They may be compared with the crystals of frost on a glass window."-G. S. p. 119.

sion. 
sion. It is chiefly visible on the south side of the canal. It appears-at Genesee River near Rochester; at Lockport on the canal, and in the great chasm of the Falls of Niagara. . Its thickness is variable; from Oneida to Palmyra (140 miles) it is 100 to 250 feet thick, and is fully displayed in this interval. It contains numerous beds of ' gypsum, and of limestone with shells. As an example of this, Mr. Eaton adduces the neighbourhood of Limestone Creek in the township of Manlius. He here "immediately on the ferriferous formation found this slate; then a bed of gypsum terminating east and west in the bank of the canal, being eight to ten perches in length; above the gypsum the slate is continued to about the thickness of sixty or seventy feet: then an extensive bed of shell-limestone occurs, ten to twelve feet in thickness, and perhaps from half a mile to a mile in breadth; then the slate again, embracing a bed of gypsum of much greater extent than that in the immediate bank of the canal. This last-mentioned slate, with its bed of gypsum, terminates the hill upwards." - (G. S. p. 126.)

The imbedded limestone is in several forms: one, which is dark gray or blue, is perforated everywhere with curvilinear holes, some being still lined with a tubular calcareous crust. The rock in the intervals of holes is very compact. Another common form is siliceous; quartzose and calcareous grains finely comminuted, being all that is essential. It is called "water lime-rock," from its property of hardening under water when used as paste or mortar. In some places it passes into. a cellular sponge-like rock, and scarcely contains any carbonate of time. It then generally abounds in petrifactions.-(P. 127.)

The calciferous slate is remarkable for its spontaneous and almost universal production of Epsom salts; alum, and copperas. Stalactites of the carbonate of lime, from a quarter to three inches in length, are common on the under surfaces of its thin slaty layers. Vast beds of calc tuff are also produced from it.

The above account of this rock is wholly that of Mr. Eaton: He also affixes to it a second appellation, "Second lgrauwacke with shell lime-rock." -I have already objected to this name. Nearly all the rock, as I have seen it at the Genesee Falls, Lockport and Niagara, is strictly an argillo-calcareous shale, in very thin brittle leaves, effervescing freely on exposure to acids; black, homogeneous, of dull lustre, and in places abounding in fossils characterizing transition limestones*. At

* Among these are two species of Caryocrinites, described by Mr. Say in the 4th volume of the Journal of the Academy of Natural Sciences of Philadelphia; and a very large and remarkable Trilobite, also described in the same volume. 
the Genesee Falls much of it, however, is pale-brown, less schistose, earthy, and interspersed with quartzose grains :-a kind of compound sandstone not to be distinguished in hand specimens from real grauwacke slate in its finer varieties.

Geodiferous Rock, - a fetid, often very massive stratum of limestone, usually very dark-coloured, but sometimes light gray, is only met with in the western half of Lake Ontario. It is distinctly seen to rest upon, and moreover to pass into the lastdescribed rock, - a fact which Mr. Eaton has not mentioned. At the Genesee River near Rochester, it is thirty feet thick, at Lockport fifty, and at Niagara seventy. (G.S. p. 135.) "Though this stratum is generally a very pure carbonate of lime, mostly a dark-coloured formless rock, yet in many re-spects it resembles the gray siliceous transition sandstone, which I have described under 'calciferous sandstone.'" They both contain geodes of quartz crystals, calcspar, and sulphate of zinc. This contains sulphate of strontian; that sulphate of barytes.-(G. S. p. 135.)

In this limestone Mr. Eaton finds "snowy gypsum, selenite, dog-tooth spar, pearl spar, fluor spar, waxy zinc blende, sulphate of strontian, and quartz crystals."-(P. 134.)

For further particulars respecting this rock, vide "Geology of the River Niagara," speedily to be published.

The two rocks next succeeding in Mr. Eaton's series are the "Cornitiferous " and "Pyritiferous Lime-rocks," of which I shall here say very little; as they belong to the River Niagara and Lake Erie. The first is essentially the same as the geodiferous, but is full of chert in nodules and layers. The second is a siliceous or calcareous rock, with an aluminous cement, and abounding in iron pyrites. Mr. Eaton considers it to be the equivalent of the pyritous shale of Whitby and Charmouth, a member of the lias formation. It is visible on the south side of Lake Ontario, but at some distance from it, from Onondago salt-springs to Lake Erie, 150 miles.-(P.145.)

The rocks of the north shore of this lake are by no means so fully nor so frequently brought into view as those of the south shore, which have now been described.

I have no doubt that, as far as they go, they are parts of the same series; but excepting the two lowest, they occur in such very small and distant patches, on the same level, and so much weathered, that to assign their geological relations is a very hazardous attempt. The salt formation certainly exists throughout its whole extent; but though I have carefully examined the greater part of the north shore (180 miles) in a boat, and passed more than once at great leisure, by land, from Kingston to York, visiting the middle parts of the rivers Trent

N.S. Vol. 5. No. 29. May 1829.

$2 \mathrm{Y}$

and 
and Moira; and crossing the height of land from this lake to that of Simcoe, I never could either see or hear of the muriatiferous rock itself. At the west end of Ontario, and throughout the eastern part of the Niagara district, it emerges in the ravines and beds of streams. Of the rocks above this, I have only seen what I consider to belong to the calciferous slate. Beginning with the lowest, I shall now give a short but sufficient sketch of the rocks of this shore in succession from the porth-east, including also those of its outlet.

Mr. Eaton found, inclining upon the gneiss of Macomb's Mountains, calciferous sandstone: on that of the Thousand Islands and of the vicinity of Kingston, there is no such stratum; but in place of it, from Brockville to seven miles above Gananoque (forty-nine miles), there is a hard quartzy sandstone in thin layers placed horizontally or nearly so. From three miles to ten miles above Brockville, it forms on the north side of the outlet extremely picturesque cliffs surmounted by green slopes, through whose herbage the gray rock occasionally peeps. Seven miles from the above town, on the same side of the river, two mounds of fine granular gneiss; within a few feet of each other, make part of the precipice without disturbing the sandstone in close contact with it. The interval between them has formed into a shallow cave. The sandstone is most plentiful on the east side of this primitive barrier; and in the interior, a few miles west and north-west of Brockville, it appears among the gneiss mounds as the precipitous sides of valleys, and as obstructions to water-courses.

This sandstone, both in large traets, and in alternating layers of the' same cliff, is gray and white, rarely spotted with carburet of iron. It is grannlar, fme and coarse, and occasionally contains nodales of crystalline quartz from the size of a mustard-seed to that of a child's heid. These nodules are seen in irregular and sometimes thick beds at the lower parts of the stratum, on the river side, from four and four and a half to seven miles above Brockiville. Here they are not of milky quartz, but are hyaline, or brown with iron, in which case the imbedding sandstone is also brown. At Gananoque this rock forms a natural quay for comneroial purposes. Here the larger nodules (white) are on the surface, the smaller scattered through the body of the layers. At the south-west end of this arenaceous platform there are many balls of sandstone six inches in diameter, with onion-like concentric coats, all of the same substance as the containing rock. . Six miles above Gananoque, the north main shore of a strait, opposite the end of Hour. Island, is composed of a pudding-stone of very large rounded masses of quartz, some of which are of the milky kind. 
They are in a cement of minute white quartzy grains. It occupies a low cliff, and is finer at the top than below, and very white. A few yards behind this is another shelf, but it is of very white and fine sandstone.

[To be continued.]

LI. Extract from a Report made on the 29th of September 1827, on the Probability of finding Coal ncar Leicester. By Mr. Francis Fonster, Mineral Surveyor, and Assayer of Coal and Iron Ore.

[With a Map.]

To the Editors of the Philosophical Magazine and Annats. Gentlemen,

IN September 1827, at the request of a person connected with coal and other mines, I made, with the assistance of my brother, Mr. M. Forster, a survey of the country surrounding Leicester, with a view to ascertain the probability of the existence of coal near that town. As circumstances have since occurred, which leave me at liberty to publish this Report, and as the opinions therein contained have also been in a great measure confirmed by the subsequent discovery of a seam of coal by boring near Bagworth (as announced in the New Monthly Magazine for July 1828, and noticed in the Phil. Mag. and Annals for March last), -I have been induced to offer an extract for publication in your valuable Magazine. Should you do me the favour to insert it, I trust that it may be found to contain hints interesting to the geologist; and I feel confident that they cannot fail to prove so to every one interested in the prosperity of Leicester.

I remain, Gentlemen, your obedient servant, 113, Aldersgate-street, London, Francis Forster. Feb. 26, 1829 .

On examining the strata in the vicinity of Leicester, it was found to consist of new red sandstone or marl, laying in nearly horizontal beds, and so completely covering over and concealing the measures beneath it, that it was found impracticable to trace the basset or outbreak of any of the subjacent strata, until I reached the transition rocks of Charnwood Forest, between which, and the new red sandstone, I was aware that the coal-beds must be found, provided they existed at all. My next step, therefore, was to examine very carefully the junction of the sandstone and transition formations, with a view to ascertain whether any coal-beds, or rocks connected therewith, made their appearance, as underlaying the sandstone, at the precise points where the latter basseted or crop- 